DOI https://doi.org/10.30525/978-9934-26-114-5-59

\title{
ФОРМУВАННЯ АНАЛІТИЧНИХ УМІНЬ У ХОДІ РОБОТИ НАД ЛІРИЧНИМ ТВОРОМ
}

\author{
Небеленчук I. O. \\ старший викладач кафедри теорії і методики середньої освіти \\ Комунальний заклад «Кіровоградський обласний інститут \\ післядипломної педагогічної освіти імені Василя Сухомлинського» \\ м. Кропивницький, Украӥна
}

Одним із найскладніших родів літератури в аспекті аналізу художнього твору є ліричний. Тож винила потреба зосередити увагу саме на аналізі ліричного твору.

Аналізу ліричних творів присвячена значна низка праць філософів, літературознавців, методистів. Варто згадати «Поетику» Аристотеля, у якій давньогрецький мислитель уперше узагальнив знання античного світу про літературу, здійснив поділ літератури на роди й описав кожний із родів. Про особливості роботи над поетичним творами читаємо у працях Г. Е. Лессінга i Й. В. Гете. Основи поетичного мистецтва виклав О. Веселовський. «Секретам поетичної творчості» надав значущості I. Франко. Аналіз поетичного твору поданий у дослідженні Ю. Лотмана. Особливості ліричних творів викладені у працях таких дослідників, як О. Галич, В. Назарець, Є. Васильєв. Зокрема дослідники зазначили, що ліричний герой $\epsilon$ важливим компонентом ліричного твору, який являє собою своєрідну уявну особистість, настрої, думки, переживання якої передані у творі [1]. Про особливості ліричної поезії дізнаємося 3 праць І. Волкова, Л. Тимофеєва, Ю. Коваліва та інших. Питанням аналізу ліричного твору присвчені праці сучасних літературознавців і методистів А. Ситеченка, Г. Клочека, Л. Мірошниченко, О Ісаєвої, Ж. Клименко, I. Небеленчук, Г. Токмань та інших. На переконання Н. Волошиної та О. Бандури, аналіз ліричного твору має бути спрямований на розгляд "[...] трьох основних компонентів: почуття й переживання, роздуми поета, зовнішні причини, щзо їх викликали (елементи сюжету)» [4, с. 344]. На переконання літературознавця Юрія Коваліва, «поезія зазвичай опирається на ірраціональність світосприйняття, відрізняючись у такий спосіб від логічних структур, потребує певної недомовленості» [2, с. 230-231]. За Є. Пасічником, «аналізувати ліричний твір - ие значить вчити дітей заглиблюватися в його 
поетичні образи, спостерігати [...], як змінюються почуття, настрої ліричного героя, чим вони викликані та як усе це безпосередньо виражається в контексті твору» [7, с. 305]. Як зазначає науковець Л. Мірошниченко, лірика «особливий рід літератури, де людина зображується здебільшого у сфері внутрішнього життя» [3, с. 292].

3-поміж наукових досліджень ліричних творів, зокрема сучасної літератури, варто виокремити авторські надбання, що спрямовані на розкриття особливостей поезії сучасних авторів. Автор досліджень презентує аналітичну діяльність творів і розкриває умови вивчення їх у шкільному курсі української літератури $[5 ; 6]$.

особливим звучанням і змістом відрізняється поезія кременчуцької поетеси Ірини Залюбовської, зокрема вірш «Поглянь на кременчуцький падолист...»: «Поглянь на кременчуцький падолист / Очима кременчуцької двірниці! / Із ракурсу такого подивись - / I через мить захочеш утопитись».

Рядки вірша відразу викликають гнітючий настрій, оскільки мозок людини найперше сприймає негатив, а слово «утопитись» наштовхує на думку про один із гріхів. Однак читаємо далі: «На недобитий вискочивщи міст, / У воду недотруєної річки / Шубовснути, оскільки падолист - / Прокляття кременчучьької двірнички».

Виникають два образи - міст і річка. Однак варто звернути увагу на те, з якими словами поєднані зазначені образи. I читаємо - «недобитий», «недотруєна». Бачимо спостережливість двірнички, яка змушена мести вулиці за певних обставин. Тож хтось і міст розбив, $\mathrm{i}$ річку отруїв. Далі вжито слово «прокляття». Хоча ідеться про падолист, який $\epsilon$ покаранням двірнички, однак розкриємо значення слова «прокляття».

Прокляття - будь-який вислів у довільній формі, що містить побажання негараздів або нещасть на адресу однієї чи декількох осіб. Часто слово «прокляття» вживається у розумінні, що шкоду або біль буде завдано надприродно. А падолист - це природне явище. То чи можемо розуміти буквально прокляття, як ми це звикли? Наслання прокляття - це думка двірнички щодо падолисту як явища загалом чи до іï роботи? Можемо стверджувати, що все таки до роботи. Проаналізувавши рядки вірша, можемо констатувати, що прокляттям людині є недотруєна річка. Доволі сильний образ, який авторка майстерно приховала за падолистом.

Лірична героїня зізнається про те, що «...nовінь золота / ...Дістала так,

ще вже не пам'ята / Нещасна та ні паспорту ні коду». Цікавими на розуміння психологічного стану ліричної героїні є слова «не пам'ята», 
«ні коду». Найчастіше поєднання «паспорт-код» дійсно люди здатні сприймати на встановлення особи. Однак слово «код» має глибше значення. Із ним $є$ такі поєднання, як-от: генетичний код, код нації, код народу, код пам'яті. А «нещасна не пам'ята». Постає запитання: «Чого саме не пам'ятає лірична героїня?» Швидше за все те, як була щаслива. На це вказують слова «вітрила», «міст», власні імена та назви «Греї», «Зурбаган», «Лісс».

Ще одним символічним образом $\epsilon$ мicm. На початку вірша читаємо про те, що лірична героїня хоче (у вірші «захочеш») утопитись, «на недобитий вискочивши міст...». Хоча авторка стверджує, що «остогидли всі на світі Греї. / I Зурбаган за обрієм, і Лісс...», однак це $\epsilon$ своєрідним психологічним прийомом. Людина, яка щось відкрито заперечує, у глибині душі про те найбільше мріє, однак хоче приховати від навколишніх, а то й навіть боїться зізнатися сама собі у чомусь. Якщо ми відштовхуємося від символічного значення слів «Грей», «Зурбаган», «Лісс», то можна стверджувати, що лірична героїня мріє про щастя, як і кожна людина.

Трапляються інші слова-символи та сполуки слів: «човенце» («Пливе візок - мале човенце вутле»), «весло» («Гребе весло спраџьована мітла»), «дев'ятий вал» («Здіймає вітер помахами крил / Дев'ятий вал кленової алеї..»).

Вираз «Мале човенце вутле» можемо розуміти як візок, у який двірники зазвичай насипають листя. Та образ човна $\epsilon$ символом людської долі, а в контексті вірша застосовано слово «човенце», та ще й «вутле», тобто слабке, хитке, ненадійне, неміцне. Убачаємо мінливість долі. У вірші авторка порівнює весло з мітлою. Одна справа, якби було тихо, а то ж «здіймає вітер... дев'ятий вал». Вітер, як природне явище, якщо він назустріч, уповільнює ходу, рух. Вітер є перешкодою - образ двозначний: здіймає листя - безпосередній образ, перешкода на шляху до здійснення чогось - опосередкований образ. Можемо стверджувати, що то життєва перешкода. На те вказує поєднання «дев'ятий вал». Дев'ятий вал - символ небезпеки, найвищого підйому грізної, непереборної сили.

Своєрідним затишшям для ліричної героїні $є$ снігопад, якому «...естафету мусить передати / Кременчука очільник Падолист». І минуть життєві негаразди. У це свято вірить лірична героїня: «Проте усе завершиться колись» - і вітер, і дев'ятий вал, і падолист, а отже негаразди і перешкоди, важка праця та двірництво.

Вірш Ірини Залюбовської глибинний і за темою, і за змістом. Це вірш про жінку, яка змушена за певних обставин коритися долі, виконуючи важку щоденну роботу, це вірш і про перешкоди, які 232 
трапляються на життєвій дорозі та які не всі люди можуть подолати. Це вірш про жіноче щастя, про яке за важкою працею навіть і подумати ніколи. Це - вірш-надія на краще та прагнення авторки вберегти хоча б одну зневірену душу від непередбачуваного кроку: «Коли життя втрачає смак і зміст - / Не пишеться, не любиться, не спиться - I Очима кременчуцької двірниці / Поглянь на кременчуцький падолист».

Це вірш також про будь-яку людину, яка змушена нести на собі хрест життя, виконуючи ту роботу, яка не до душі. А ще про розпач $\mathrm{i}$ біль, небезпеку та перешкоди, зневіру та безнадію, однак як і надію.

Вірші Ірини Залюбовської насичені метафорами, милозвучними римами, особливими образами - від скандинавської міології до сучасної дійсності. Тому можуть бути предметом досліджень науковців i методистів і можуть бути розглянуті в контексті вивчення розділів «Сучасна українська література: поезія» та «Література рідного краю».

\section{Література:}

1. Галич О., Назарець В., Васильєв С. Теорія літератури: Підручник / За наук. ред. О. Галича. К., 2001. С. 285-286.

2. Літературознавча енциклопедія : у 2 т. / авт.-уклад. Ю. І. Ковалів. Київ : ВЦ «Академія», 2007. Т. 2 : М - Я. С. 230-231.

3. Мірошниченко Л. Ф. Методика викладання світової літератури в середніх навчальних закладах: Підручник.. К. : Вища школа, 2007. $415 \mathrm{c}$.

4. Наукові основи методики літератури: навч.-метод. посіб. / За ред. Н. Й. Волошиної. К. : Ленвіт, 2002. 344 с.

5. Небеленчук I. О. Аксіологічний імператив збірки «Хліб для янгола» Віктора Крупки. Стан освітнього процесу в умовах викликів сьогодення : матеріали Міжнародної науково-практичної конференції (Дніпро, 12 лютого 2021 р). Дніпро : Міжнародний гуманітарний дослідницький центр, 2021. С. 36-39.

6. Небеленчук I. О. Концепт молитви як один із сенсів духовного життя людини у збірці «Цілую Твій поділ» Ліни Ланської. Актуальні питання гуманітарних наук. Вип. 33, том 1, 2020. С. 221-227.

7. Пасічник $Є$. А. Методика викладання української літератури в середніх навчальних закладах: навч. посіб. для студ. вищих навчальних закладів освіти. К. : Ленвіт, 2000. 384 с. 